\title{
INVESTIGATING DRIVERS AND BARRIERS FOR THE DEVELOPMENT OF PRODUCT-SERVICE SYSTEMS IN CAPITAL GOODS MANUFACTURING COMPANIES
}

\author{
Sarancic, David; \\ Pigosso, Daniela C. A.; \\ McAloone, Tim C. \\ Technical University of Denmark
}

\begin{abstract}
The purpose of this paper is to showcase initial considerations taken in the process of Product-Service Systems (PSS) development in the capital goods manufacturing companies. The focus is on the identification of both generic drivers and barriers that typically present themselves. Drivers and barriers are classified and compared, with respect to developed dimensions that aim to encompass different aspects relevant to PSS development. The classification presented in this paper has promise when researching how to support companies that aspire to develop and implement PSS, both to invigorate internal motivation for change and to understand crucial obstacles that might arise in the process. Furthermore, a chain of discovered motives and challenges for PSS is discussed, in an attempt to relate and connect the general manufacturing industry to the capital goods manufacturing industry.
\end{abstract}

Keywords: Product-Service Systems (PSS), Systems Engineering (SE), Circular economy, Drivers, Barriers

\section{Contact:}

Sarancic, David

Technical University of Denmark

Engineering Design \& Product Development

Denmark

dasar@mek.dtu.dk

Cite this article: Sarancic, D., Pigosso, D. C. A., McAloone, T. C. (2021) 'Investigating Drivers and Barriers for the Development of Product-Service Systems in Capital Goods Manufacturing Companies', in Proceedings of the International Conference on Engineering Design (ICED21), Gothenburg, Sweden, 16-20 August 2021. DOI:10.1017/ pds. 2021.454 


\section{INTRODUCTION}

Over recent decades, the focus within the manufacturing industry has been on faster throughput, accelerating the business and producing more with the same set of resources and the same infrastructure setup (Tersine and Hummingbird, 1995). Despite great advancements in production and product quality, the basic societal model of transfer of ownership remained a prevalent instrument of value creation (Prahalad and Ramaswamy, 2004). The current issue of commoditisation of products, the ever enhancing price competition and the unsustainable patterns of production and consumption call for the need to move towards a service-based model, where value is created through a combination of products and services (Matthyssens and Vandenbempt, 2008).

At the same time, manufacturing companies and organizations alike are recognizing the potential of tapping into the Circular Economy (CE), both from sustainability and competitive advantage perspectives (de Angelis, 2018). CE is developing as a response to the linear "take-make-dispose" paradigm of resource exploitation (Ellen MacArthur Foundation, 2015). CE is regarded as a potentially more sustainable post-production business model (Stahel, 2013), as it paves the way to a different logic of value creation - in a closed loop.

One concrete concept that addresses the challenge on how to capitalize on the new paradigm of the CE is that of Product-Service Systems (PSS) (Devisscher and Mont, 2008; Tukker, 2015). PSS advocates revenue generation through an increasingly pervasive service-dominant logic and total solution offerings, rather than sales of physical products (Martinez et al., 2010; Opresnik et al., 2013). The goal that is aimed to be achieved through PSS is to develop a solution in which business drivers are mutually reinforcing the sustainability agenda (Roy, 2000; Tukker, 2004). According to Kjaer et al. (2019), PSS can be seen as an enabler of resource reduction through product longevity, operational efficiency and intensified product usage which consequently reduce the need for producing more products. However, it is not necessarily the case that a final PSS solution will lead to sustainability improvements (Manzini and Vezzoli, 2003).

Diverse definitions encompass various aspects of PSS and set very different boundaries on the comprehensiveness of the concept (Haase et al., 2017; McAloone, 2011). According to Haase et al., (2017), the most cited definition of PSS is: “... a PSS is an integrated product and service offering that delivers value in use. A PSS offers the opportunity to decouple economic success from material consumption and hence reduce the environmental impact of economic activity" (Baines et al., 2007).

Despite the many definitions and tools to guide the industry to explore the potential PSS opportunities, develop PSS solutions, and subsequently evaluate the sustainability benefits of their solutions, many authors state there is still a lack of knowledge to address those challenges (Kim and Lee, 2020; Mendes et al., 2015; Vezzoli et al., 2018). The knowledge gap of how to define and guide PSS towards the potential benefits grows even more when focusing the scope of the industry branch to the specific sector of capital goods manufacturing (Adrodegari et al., 2018), where PSS has significant potential, but also encounters specific challenges, due to long-lived installed bases and heavy investment products.

Capital goods manufacturing firms still heavily rely on sales of physical products, where around $26 \%$ of the revenue on average comes from services (Adrodegari et al., 2018). In such a paradigm, the original equipment manufacturer is not incentivised to make more durable machines, due to the majority of the revenue coming from the transfer of ownership of machines to the company's customers. There are increasing examples, however, of some capital goods manufacturers, shifting the mode of business operation towards greater shares of revenue earned from through-life services, rather than single product transactions (Adrodegari et al., 2018; Gebauer et al., 2010). In such sectors, there is a pronounced need to distinguish between how to develop and implement PSS on new products versus the already existing installed base.

Focusing on the capital goods manufacturing sector, this paper aims to chart the initial steps and contemplations taken in the process of PSS development, with the intention of identifying, mapping and comparing generic drivers and barriers in the manufacturing industry with the drivers and barriers that are more particular to capital goods manufacturers. 


\section{RESEARCH METHODOLOGY}

The main objective of this paper is to explore and categorize drivers and barriers for manufacturing companies to introduce PSS, with a particular focus on the sub-category of capital goods manufacturing companies.

The empirical context for this research is a capital goods manufacturer, producing machinery for the food and beverage industry, which at the time of writing was in the early stages of adoption of PSS for its business. The company had the ambition to adopt PSS as a means of increasing its competitiveness on the market, whilst at the same time contributing to its sustainability strategy, by prolonging the life and increasing the effectiveness of its products in the field. The focus of the research case is, therefore, to support capital goods manufacturers in PSS development.

Based on the objective, three research questions were formulated:

1. What are the main drivers or motives for a manufacturing company to introduce a PSS?

2. What are the main barriers or challenges for a manufacturing company to introduce PSS?

3. What are the differences and similarities of identified drivers and barriers between manufacturing companies in general and specifically capital goods manufacturing companies?

A literature review was conducted to tackle the research questions and a review protocol was created, containing three main activities: data collection, analysis and reporting (de Almeida Biolchini et al., 2007). Data collection was conducted by searching the Scopus database, where many articles were uncovered using the keywords "PSS", "driver", "barrier", "capital goods" and their synonyms. Two different search strings were defined; the first explored the drivers and barriers for PSS development in the manufacturing industry in general and the other focused on capital goods manufacturers. Both search strings can be seen in Table 1.

Table 1. Search strings used in the scopus database and applied to title, keywords and abstracts of the search field.

\begin{tabular}{|c|c|c|}
\hline Target & Manufacturing Industry in General (MIIG) & Capital Goods Manufacturers (CGM) \\
\hline $\begin{array}{l}\text { Search } \\
\text { string }\end{array}$ & $\begin{array}{l}\text { ( ( "PSS" OR "Product Service System*" OR "Functional Sale*" OR } \\
\text { "service oriented" OR "Integrated Product Service*" OR "Service* } \\
\text { Engineering" OR "Product Bund*" OR "Performance based } \\
\text { contracting" OR "Solution* based partnership*") AND ( "Drive*" } \\
\text { OR "Barrie**" OR "Challenge*" OR "Motiv*" OR "limit*" OR } \\
\text { "incentive*" OR "obstacle*" OR "hurdle*" OR "difficult*" OR } \\
\text { "stimu*" OR "hinderance*" OR "trigger*" OR "shortcoming*" OR } \\
\text { "risk*" OR "problem*" OR "issue*" OR "catalyst*" OR } \\
\text { "impediment*" OR "complication*") AND ( "manufact*") AND ( } \\
\text { "industr*") AND ( "serviti?ation") AND ( "compan*" OR } \\
\text { "enterprise*" OR "firm*" OR "business*") AND ( "sustain*" OR } \\
\text { "circula**" OR "environment*") ) }\end{array}$ & $\begin{array}{l}\text { ( ( "PSS" OR "Product Service System" OR "Functional } \\
\text { Sale*" OR "service oriented" OR "Integrated Product } \\
\text { Service*" OR "Service* Engineering" OR "Product } \\
\text { Bundl*" OR "Performance based contract*" OR "Solution? based } \\
\text { partnership*") AND ( "Drive*" OR "Barrier*" OR "Challenge*" OR } \\
\text { "Motiv*" OR "limit*" OR "incentive*" OR "obstacle*" OR "hurdle } \\
\text { *" OR "difficult*" OR "stimul*" OR "hinderance*" OR "trigger*" O } \\
\text { R "shortcoming*" OR "risk*" OR "problem*" OR "issue*" OR "cat } \\
\text { alyst*" OR "impediment*" OR "complication*") AND ( "Capital } \\
\text { Good*" OR "capital equipment" OR "capital resource*" OR "capital } \\
\text { asset*" OR "capital machine*")) AND ( "manufact*") }\end{array}$ \\
\hline Results & 1,745 & 457 \\
\hline
\end{tabular}

The lists of publications obtained through the searches were then filtered by the number of citations and the titles were checked to ensure relevance to the review. Additionally, the backward snowballing approach (Wohlin, 2014) was applied to include other relevant publications through cross-referencing. The literature review finally resulted in 26 publications, which were included in the analysis, which were chosen due to their significantly higher citation rates.

From the set of 26 publications, 29 drivers and 40 barriers were identified for PSS development and implementation. Of those, 29 drivers and 35 barriers were identified to be related to the manufacturing companies in general and 8 drivers and 17 barriers related to capital goods manufacturers.

The drivers and barriers were classified by the authors according to 10 developed dimensions using affinity clustering. The dimensions were formed inductively through the identification of emergent patterns. Various concepts extracted from the drivers and barriers review were sorted as clusters in one of the dimensions axiomatically, in an attempt to make the comprehension of the multitude of items easier. Dimension nomenclature was adopted to cover its whole content with one overarching headline. This heuristic classification served to facilitate the driver and barrier classification and representation, while the purpose of dimensions themselves was to direct the attention of practitioners to all the uncovered concepts in a structured and chronological depiction. In Table 2, the dimension clusters are represented along with their headlines. The dimensions are ordered to follow the life cycle perspective as closely as possible to introduce a logical flow. 
Table 2. 10 Dimensions used to classify concepts extracted from driver and barrier analysis.

\begin{tabular}{|c|c|c|c|}
\hline Dimension & Concept & Dimension & Concept \\
\hline \multirow{7}{*}{ 1. Strategy } & Diversification & \multirow{4}{*}{ 6. Traceability } & Digitalisation \\
\hline & Competitiveness & & Installed base \\
\hline & Value Proposition & & Usage \\
\hline & Differentiation & & Data \\
\hline & Business model & \multirow{2}{*}{ 7. Regulatory } & Responsibility \\
\hline & Demonetisation & & Transparency \\
\hline & Quality & \multirow{7}{*}{ 8. Change Managment } & Competencies Development \\
\hline \multirow{6}{*}{ 2. Development } & Innovation & & Duration of Change \\
\hline & Complexity & & Job creation \\
\hline & Methodology & & Culture Change \\
\hline & Design & & Organisation Change \\
\hline & Service Engineering & & Management Change \\
\hline & Systems Engineering & & Readiness \\
\hline \multirow{4}{*}{ 3. Decision-making } & Trade-offs & \multirow{7}{*}{ 9. Economic Sustainability } & Stability \\
\hline & Hidden elements & & Cost Reduction \\
\hline & Risk & & Market Demand \\
\hline & Uncertainty & & Opportunities \\
\hline \multirow{5}{*}{ 4. Ecosystem } & External stakeholders & & Growth \\
\hline & Network & & Revenue \\
\hline & Actors & & Investment \\
\hline & Communication & \multirow{4}{*}{$\begin{array}{l}\text { 10. Environmental } \\
\text { Sustainability }\end{array}$} & Resources \\
\hline & Marketing & & End-of-life \\
\hline \multirow{2}{*}{ 5. Access } & Ownership & & Lifecycle \\
\hline & Democratisation & & Dematerialisation \\
\hline
\end{tabular}

\section{RESULTS}

The first observation of the review results concerns the timing and development of drivers and barriers, where the majority of publications uncovered in the review come from developed countries in Europe, led by the UK, Germany, Italy and Scandinavia.

After a number of publications in the early 2000s, the field of PSS picks up the pace and shows a steep increasing trend after 2009. This trend might be associated with the fact that PSS becomes increasingly interesting within the Circular Economy that started to slowly gain traction at the same time.

According to Mont (2004), the drivers, but also barriers for shifting to a more service-oriented business are many, both external and internal, within the company. The recent literature on PSS seems to confirm both the early findings on advantages and disadvantages (Tukker, 2015).

The following sections present the drivers and barriers identified in the literature, respectively. Two types of analysis have been conducted: (1) mapping of the presence of drivers and barriers within (a) manufacturing industry in general and (b) capital goods manufacturing companies; and (2) affinity mapping and clustering. Drivers and barriers were classified into dimensions by affiliation to the concepts previously assigned to one of the 10 dimensions. Some of the drivers and barriers may be assigned to multiple dimensions, indicating the complexity of considerations to be taken in PSS development.

\subsection{Drivers}

The whole manufacturing industry within developed economies has been undergoing a transition from costdriven to value- and knowledge-based (Mont, 2002), in order to keep a distance from the pressure created by lower-cost economies (Vezzoli et al., 2015). However, this pressure is just one of many factors that incentivise the development and implementation of PSS.

Other drivers, 29 of them in total, were uncovered in the literature and the key points of the analysis of all drivers gathered literature are presented in Table 3 . Each of the drivers is referenced according to the reference key in the appendix. They are sorted to first present the drivers in the general manufacturing industry, then ones that are present in both cases. Furthermore, the drivers are sorted by the incidence of their appearance in literature, starting from the highest on the top. The order of drivers does not necessarily represent their importance, as those are circumstance dependent for each company. 
Table 3. Drivers for PSS development and implementation identified in the literature.

\begin{tabular}{|c|c|c|c|c|c|c|c|c|c|c|c|c|c|c|}
\hline \multirow[b]{2}{*}{ \# } & \multirow[b]{2}{*}{ Driver for PSS Development } & \multicolumn{2}{|c|}{\begin{tabular}{|c|} 
Categories \\
\end{tabular}} & \multicolumn{10}{|c|}{ Dimensions } & \multirow[b]{2}{*}{ 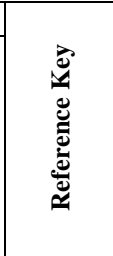 } \\
\hline & & 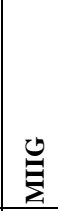 & $\sum_{U}$ & 尝 & 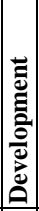 & 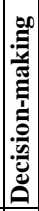 & 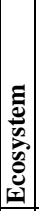 & 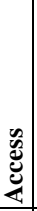 & 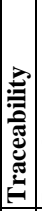 & 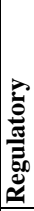 & 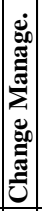 & 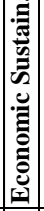 & 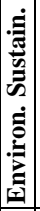 & \\
\hline 1 & $\begin{array}{l}\text { To understand and improve customer and network relationships and develop loyalty } \\
\text { through greater involvement, interaction and knowledge sharing. }\end{array}$ & $\mathrm{X}$ & & $\mathrm{x}$ & & & $\mathrm{x}$ & & $\mathrm{x}$ & & & & & \begin{tabular}{|l}
{$[3],[4],[5]$,} \\
{$[12],[17]$,} \\
{$[24]$}
\end{tabular} \\
\hline 2 & $\begin{array}{l}\text { To strategically safeguard and explore new market, business opportunities and profit } \\
\text { centres }\end{array}$ & $\mathrm{x}$ & & $\mathrm{x}$ & & $\mathrm{x}$ & & & & & $\mathrm{x}$ & $\mathrm{x}$ & & \begin{tabular}{|l|}
{$[1],[2],[4]$,} \\
{$[5],[11],[18]$}
\end{tabular} \\
\hline 3 & $\begin{array}{l}\text { To shift to more environmentally sustainable practices and reduce environmental } \\
\text { impact. }\end{array}$ & $\mathrm{x}$ & & $\mathrm{x}$ & & & & & & & & & $\mathrm{x}$ & $\begin{array}{l}{[2],[3],[4],} \\
{[5],[6],[7]}\end{array}$ \\
\hline 4 & $\begin{array}{l}\text { To lower the initial investment access barrier for customers through ownership sharing } \\
\text { and extended producer responsibilities. }\end{array}$ & $\mathrm{X}$ & & $\mathrm{x}$ & & $\mathrm{x}$ & $\mathrm{x}$ & $\mathrm{x}$ & & $\mathrm{x}$ & & $\mathrm{x}$ & & \begin{tabular}{|l}
{$[2],[3],[4]$,} \\
{$[11],[17]$} \\
\end{tabular} \\
\hline 5 & $\begin{array}{l}\text { To be internally incentivised to design products for one or several of the following } \\
\text { characteristics: long life, upgrade, durability, access, recyclability, maintenance, } \\
\text { service, monitoring, quality, efficiency and closed loop. }\end{array}$ & $\mathrm{x}$ & & $\mathrm{x}$ & $\mathrm{x}$ & & & $\mathrm{x}$ & $\mathrm{x}$ & & & & $\mathrm{x}$ & $\begin{array}{l}{[4],[7],[14],} \\
{[17]}\end{array}$ \\
\hline 6 & $\begin{array}{l}\text { To reduce resource consumption and the total number of products while still delivering } \\
\text { the same or greater value and consequently reduce both material costs and waste. }\end{array}$ & $\mathrm{x}$ & & $\mathrm{x}$ & & & & & & & & $\mathrm{x}$ & $\mathrm{x}$ & {$[2],[4],[17]$} \\
\hline 7 & $\begin{array}{l}\text { To enable flexibility in delivering customised offerings to customers as an alternative } \\
\text { to standardisation and mass production. }\end{array}$ & $\mathrm{x}$ & & $\mathrm{x}$ & $\mathrm{x}$ & & $\mathrm{x}$ & & & & $\mathrm{x}$ & $\mathrm{x}$ & & [2], [4], [17] \\
\hline 8 & To facilitate easier communication about the whole product-service package offering & $\mathrm{X}$ & & & & & $\mathrm{x}$ & & $\mathrm{x}$ & & & & & [2], [4] \\
\hline 9 & To secure lifecycle and aftermarket control. & $\mathrm{X}$ & & $\mathrm{X}$ & $\mathrm{X}$ & $\mathrm{X}$ & $\mathrm{x}$ & & & & $\mathrm{x}$ & $\mathrm{x}$ & & [1], [4] \\
\hline 10 & $\begin{array}{l}\text { To facilitate continuous and accelerated innovation within the company due to closer } \\
\text { customer contact }\end{array}$ & $\mathrm{x}$ & & $\mathrm{x}$ & $\mathrm{x}$ & $\mathrm{x}$ & $\mathrm{x}$ & & & & $\mathrm{x}$ & & & [3], [4] \\
\hline 11 & $\begin{array}{l}\text { To anticipate and comply with future environmental legislation and facilitate the } \\
\text { development of more efficient policies. }\end{array}$ & $\mathrm{X}$ & & $\mathrm{x}$ & & & & & & $\mathrm{x}$ & & & $\mathrm{x}$ & [4], [11] \\
\hline 12 & To improve internal core competencies. & $\mathrm{x}$ & & $\mathrm{x}$ & $\mathrm{X}$ & & & & & & $\mathrm{x}$ & & & [4], [17] \\
\hline 13 & $\begin{array}{l}\text { To get access to the installed base of products in order to be able to provide } \\
\text { monitoring, maintenance and repair services. }\end{array}$ & $\mathrm{x}$ & & $\mathrm{x}$ & & & $\mathrm{x}$ & & $\mathrm{x}$ & $\mathrm{x}$ & & $\mathrm{x}$ & & [4], [15] \\
\hline 14 & $\begin{array}{l}\text { To move a step closer to take-back schemes and potentially reuse and recycle } \\
\text { materials and components. }\end{array}$ & $\mathrm{X}$ & & $\mathrm{x}$ & $\mathrm{x}$ & & & & & $\mathrm{x}$ & & $\mathrm{x}$ & $\mathrm{x}$ & [2], [4] \\
\hline 15 & $\begin{array}{l}\text { To compensate for largely exhausted possibilities to invent new solutions within the } \\
\text { technical realm of mature industries. }\end{array}$ & $\mathrm{x}$ & & $\mathrm{x}$ & & & & & & & & $\mathrm{x}$ & & [1] \\
\hline 16 & $\begin{array}{l}\text { To take advantage of the facts that PSS solutions have been more readily accepted in } \\
\text { the communal societies of Scandinavia, the Netherlands, and Switzerland. }\end{array}$ & $\mathrm{X}$ & & $\mathrm{x}$ & & & $\mathrm{x}$ & & & & & $\mathrm{x}$ & & [20] \\
\hline 17 & $\begin{array}{l}\text { To exploit the window of opportunity with the rise of sharing economy and } \\
\text { collaborative consumption. }\end{array}$ & $\mathrm{x}$ & & $\mathrm{x}$ & & & & & & & & $\mathrm{x}$ & $\mathrm{x}$ & {$[17]$} \\
\hline 18 & To create jobs in more intensive labour functional economy & $\mathrm{X}$ & & $\mathrm{X}$ & & & $\mathrm{X}$ & & & & & & & [4] \\
\hline 19 & To ensure transparency about environmental features for customers & $\mathrm{X}$ & & & & & & & & $\mathrm{x}$ & & & $\mathrm{X}$ & [4] \\
\hline 20 & To save time in value delivery. & $\mathrm{X}$ & & & $\mathrm{X}$ & $\mathrm{X}$ & $\mathrm{X}$ & & & & & $\mathrm{x}$ & & [3] \\
\hline 21 & $\begin{array}{l}\text { To potentially decouple environmental pressure from economic growth by focusing on } \\
\text { asset use rather than on asset ownership. }\end{array}$ & $\mathrm{x}$ & & $\mathrm{x}$ & & & $\mathrm{x}$ & $\mathrm{x}$ & & & & $\mathrm{x}$ & $\mathrm{x}$ & [2] \\
\hline 22 & $\begin{array}{l}\text { To strategically differentiate from the competition and ensure competitiveness with } \\
\text { supplement service offerings that are difficult to imitate. }\end{array}$ & $\mathrm{x}$ & $\begin{array}{c}\mathrm{X}[7], \\
{[13]}\end{array}$ & $\mathrm{x}$ & $\mathrm{x}$ & & $\mathrm{x}$ & & & & & $\mathrm{x}$ & & \begin{tabular}{|l} 
[2], [4], [5], \\
{$[6]$, [7], [8, } \\
{$[9],[13],[16]$}
\end{tabular} \\
\hline 23 & $\begin{array}{l}\text { To maintain, increase or diversify revenue streams and ensure resistance to economic } \\
\text { cycles and stable recurring income with services. }\end{array}$ & $\mathrm{x}$ & $\mathrm{X}[7]$ & $\mathrm{x}$ & & & & & & & & $\mathrm{x}$ & & \begin{tabular}{|l}
{$[4],[5],[6]$,} \\
{$[7],[17]$}
\end{tabular} \\
\hline 24 & To deliver extra total value and higher quality offerings to customers & $\mathrm{X}$ & $\mathrm{X}[7]$ & $\mathrm{x}$ & $\mathrm{x}$ & & $\mathrm{x}$ & & & & & & & \begin{tabular}{|l|}
$2],[4],[7]$, \\
{$[17]$}
\end{tabular} \\
\hline 25 & To use service to influence purchasing decisions and sell more products. & $\mathrm{x}$ & $\mathrm{x}[7]$ & $\mathrm{x}$ & & & $\mathrm{x}$ & & & & $\mathrm{x}$ & $\mathrm{x}$ & & \begin{tabular}{|l|}
$5],[7],[10]$, \\
{$[23]$}
\end{tabular} \\
\hline 26 & $\begin{array}{l}\text { To free customers of, often undesirable, administrative or monitoring tasks and } \\
\text { problems associated with maintenance and disposal of equipment. }\end{array}$ & $\mathrm{x}$ & $\mathrm{x}[7]$ & & $\mathrm{x}$ & & $\mathrm{x}$ & $\mathrm{X}$ & & $x$ & & & & {$[2],[7],[17]$} \\
\hline 27 & $\begin{array}{l}\text { To seize the contextual opportunities such as inherent more intensive use of capital } \\
\text { goods and a bigger chance of gaining through services for a final product manufacturer } \\
\text { then the component manufacturer. }\end{array}$ & $\mathrm{x}$ & $\mathrm{X}[3]$ & $\mathrm{x}$ & & & & & & & $\mathrm{x}$ & $\mathrm{x}$ & & [1], [3] \\
\hline 28 & $\begin{array}{l}\text { To capitalize on the possibility of manufacturers with high-installed product bases, } \\
\text { where service revenues can be one or two orders of magnitude greater than the new } \\
\text { product sale. }\end{array}$ & $\mathrm{X}$ & $\begin{array}{c}\mathrm{X}[5] \\
{[20]}\end{array}$ & $\mathrm{X}$ & & & & $\mathrm{x}$ & $\mathrm{x}$ & & $\mathrm{x}$ & $\mathrm{x}$ & & {$[5],[20]$} \\
\hline 29 & To develop suppliers. & $\mathrm{X}$ & $\mathrm{X}[15]$ & $\mathrm{X}$ & $\mathrm{X}$ & & $\mathrm{X}$ & & & & $\mathrm{X}$ & $\mathrm{x}$ & & {$[4],[15]$} \\
\hline
\end{tabular}

\subsection{Barriers}

There are various prohibitive factors for PSS development and implementation, depending on the desired service content added in the process of transition to PSS. Cost and retraining of the workforce can be particularly limiting factors when considering the transition to PSS (Tukker, 2015). 
Forty barriers were uncovered from the selected literature and are presented in Table 4. Each of the barriers is referenced according to the reference key in the appendix. They are sorted to first present the barriers in the general manufacturing industry, then ones that are present in both cases, and finally the ones that only relate to the capital goods manufacturers. Furthermore, the barriers are sorted by the incidence of their appearance in the literature, starting from the highest on the top. The order of drivers does not necessarily represent their importance, as those are circumstance dependent for each company.

Table 4. Drivers for PSS development and implementation identified in the literature.

\begin{tabular}{|c|c|c|c|c|c|c|c|c|c|c|c|c|c|c|}
\hline \multirow[b]{2}{*}{$\#$} & \multirow[b]{2}{*}{ Barriers for PSS Development } & \multicolumn{2}{|c|}{ Categories } & \multicolumn{10}{|c|}{ Dimensions } & \multirow[b]{2}{*}{ 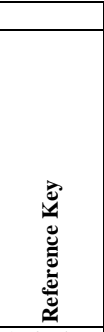 } \\
\hline & & $\stackrel{\Xi}{\Sigma}$ & $\sum_{0}^{\top}$ & & & 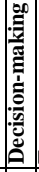 & 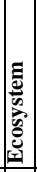 & 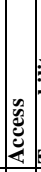 & 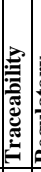 & & 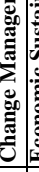 & & 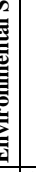 & \\
\hline 1 & Internal and external resistance to change and extended responsibility. & $\mathrm{x}$ & & & $\mathrm{x}$ & & $\mathrm{x}$ & & & & $\mathrm{x}$ & & & $\begin{array}{l}{[1],[2],[4],} \\
{[5],[10],[11]}\end{array}$ \\
\hline 2 & Difficulties to select, involve and coordinate relevant stakeholders in the design process. & $\mathrm{x}$ & & & $\mathrm{x}$ & $\mathrm{x}$ & $\mathrm{x}$ & & & & & & & \begin{tabular}{l|l}
{$[2],[4],[11]$,} \\
{$[14],[17]$}
\end{tabular} \\
\hline 3 & $\begin{array}{l}\text { Lack of experience, methodologies and competencies to design complex systems for high intangible value and } \\
\text { implement it business-wide. }\end{array}$ & $\mathrm{x}$ & & $\mathrm{x}$ & $\mathrm{x}$ & & $\mathrm{x}$ & & $\mathrm{x}$ & & $\mathrm{x}$ & & & [2], [3], [5], \\
\hline 4 & $\begin{array}{l}\text { Diversity of services rather than products means competition outside the usual domain and unexpected rivals } \\
\text { including own suppliers and distributors. }\end{array}$ & $\mathrm{x}$ & & $\mathrm{x}$ & $\mathrm{x}$ & & $\mathrm{x}$ & & & & & $\mathrm{x}$ & & $\begin{array}{l}{[5],[7],[10],} \\
{[24]}\end{array}$ \\
\hline 5 & $\begin{array}{l}\text { The changeover in business models and the system of profit generation accompanies with complicated revenue- } \\
\text { sharing schemes and long amortisation periods. }\end{array}$ & $\mathrm{x}$ & & $\mathrm{x}$ & $\mathrm{x}$ & & $\mathrm{x}$ & & & & $\mathrm{x}$ & $\mathrm{x}$ & & $\begin{array}{l}\text { [2], [4], [14], } \\
{[24]}\end{array}$ \\
\hline 6 & $\begin{array}{l}\text { Concerns about the time required to transform offerings and implement extra environmental considerations in the } \\
\text { development process. }\end{array}$ & $\mathrm{x}$ & & $\mathrm{x}$ & $\mathrm{x}$ & & & & & & $\mathrm{x}$ & $\mathrm{x}$ & $\mathrm{x}$ & [1], [2], [4] \\
\hline 7 & Possible rebound effects due to careless customer behaviour when not owing a product. & $\mathrm{x}$ & & & & & & & $\mathrm{x}$ & $\mathrm{x}$ & & & $\begin{array}{ll}x & {[3} \\
\end{array}$ & [3], [17], [26] \\
\hline 8 & $\begin{array}{l}\text { Managers must be convinced that people are their main asset, and people have to be convinced that sales of } \\
\text { business solutions are a good idea before they can convince customers. }\end{array}$ & $\mathrm{x}$ & & & & & $\mathrm{x}$ & & & & & & & [5], [10], [22] \\
\hline 9 & Development and visualisation of scenarios for alternative product use and the elements of the future system. & $\mathrm{x}$ & & & $\mathrm{x}$ & $\mathrm{x}$ & $\mathrm{x}$ & & & & $\mathrm{x}$ & & & [4], [14] \\
\hline 10 & New legal conditions and a variety of regulatory frameworks in different countries. & $\mathrm{x}$ & & & & & $\mathrm{x}$ & & & $\mathrm{x}$ & & & & [4], [14] \\
\hline 11 & Possible lack of customer's interest in use rather than ownership. & $\mathrm{x}$ & & & & & $\mathrm{x}$ & $\mathrm{x}$ & & & & & & [4], [24] \\
\hline 12 & The complexity of design, implementation and assessment of systemic changes. & $\mathrm{x}$ & & & $\mathrm{x}$ & & & & & & $\mathrm{x}$ & & & [2], [17] \\
\hline 13 & Modelling and verification of PSS development processes. & $\mathrm{x}$ & & & $\mathrm{x}$ & & & & & & $\mathrm{x}$ & & & [14] \\
\hline 14 & $\begin{array}{l}\text { PSS could leave the impression that the provider prescribes how a customer should behave - behavioural } \\
\text { freedom taken away. }\end{array}$ & $\mathrm{x}$ & & & & & $\mathrm{x}$ & & & & & & & [24] \\
\hline 15 & $\begin{array}{l}\text { Possible negative interactions of new customer-oriented part of the business with existing (product-oriented) } \\
\text { business actor }\end{array}$ & $\mathrm{x}$ & & & & & $\mathrm{x}$ & & & & & & & [24] \\
\hline 16 & Estimation of both companies' and customers' readiness to accept PSS. & $\mathrm{x}$ & & $\mathrm{x}$ & & & $\mathrm{x}$ & & & & $\mathrm{x}$ & $\mathrm{x}$ & & [4] \\
\hline 17 & $\begin{array}{l}\text { Lack of understanding of environmental impacts of PSS that is not necessarily smaller and its dependence on } \\
\text { circumstances. }\end{array}$ & $\mathrm{x}$ & & $\mathrm{x}$ & & & & & & & & & $\left.\mathrm{x}\right|_{[4}$ & [4] \\
\hline 18 & Problem of overdiversification. & $\mathrm{x}$ & & $\mathrm{x}$ & & & $\mathrm{x}$ & & & & & $\mathrm{x}$ & & [1] \\
\hline 19 & $\begin{array}{l}\text { Cultural and corporate change from traditional manufacturing mindset based on owing and selling products to } \\
\text { service culture where value is placed on having a need met. }\end{array}$ & $\mathrm{x}$ & $\mathrm{x}[7]$ & $\mathrm{x}$ & & & $\mathrm{x}$ & & & & & & & $\begin{array}{l}{[2],[4],[5],} \\
{[7],[10],[17],} \\
{[20],[21]}\end{array}$ \\
\hline 20 & Adoption of new organisational strategy, structure and processes & $\mathrm{x}$ & $\begin{array}{r}\mathrm{x}[7], \\
{[12]}\end{array}$ & & $\mathrm{x}$ & & $\mathrm{x}$ & & & & $\mathrm{x}$ & & & $\begin{array}{l}{[5],[7],[9],} \\
{[10],[12],} \\
{[14],[17]}\end{array}$ \\
\hline 21 & Limited knowledge of operating risks, costs and pricing mechanisms. & $\mathrm{x}$ & $\begin{array}{c}\mathrm{X}[12] \\
{[15]}\end{array}$ & & $\mathrm{x}$ & & $\mathrm{x}$ & & & & & $\mathrm{x}$ & & $\begin{array}{l}\text { [2], [3], [12], } \\
{[14],[15],} \\
{[17],[24]}\end{array}$ \\
\hline 22 & Difficulty to clearly define offerings, set unambiguous performance indicators and trace the transition progress. & $\mathrm{x}$ & $\mathrm{x}[7]$ & & $\mathrm{x}$ & $\mathrm{x}$ & & & & & $\mathrm{x}$ & & & $\begin{array}{l}{[3],[4],[5][7],} \\
{[17],[21]}\end{array}$ \\
\hline 23 & $\begin{array}{l}\text { Common and transparent knowledge sharing and clear communication about the new value proposition across } \\
\text { the network. }\end{array}$ & $\mathrm{x}$ & $\mathrm{x}[7]$ & $\mathrm{x}$ & & & $\mathrm{x}$ & & $\mathrm{x}$ & & $\mathrm{x}$ & & & $\begin{array}{l}\text { [4], [5], [7], } \\
{[10],[14]}\end{array}$ \\
\hline 24 & $\begin{array}{l}\text { Challenges in building and operating a network of long-lasting partnerships to support geographically distributed } \\
\text { installed base. }\end{array}$ & $\mathrm{x}$ & $\mathrm{x}[7]$ & $\mathrm{x}$ & & & $\mathrm{x}$ & & & & & & & {$[4],[7],[12]$,} \\
\hline 25 & $\begin{array}{l}\text { The need to train and qualify staff for new offering provision that includes both product and relationship } \\
\text { management skills. }\end{array}$ & $\mathrm{x}$ & $\mathrm{X}[12]$ & & & & $\mathrm{x}$ & & & & $\mathrm{x}$ & & & [12], [14], \\
\hline 26 & Inexperience with the total cost of ownership models. & $\mathrm{x}$ & $\left.\begin{array}{r}\mathrm{X}[12] \\
{[13]}\end{array}\right]$ & & $\mathrm{x}$ & & $\mathrm{x}$ & & & & & $\mathrm{x}$ & & [12], [13], [20] \\
\hline 27 & Balance and trade-offs between environmental goals, partnerships, customer needs and the development process. & $\mathrm{x}$ & $\mathrm{x}[15]$ & $\mathrm{x}$ & & $\mathrm{x}$ & $\mathrm{x}$ & & & & & $\mathrm{x}$ & $\left.x\right|_{[1}$ & [1], [4], [15] \\
\hline 28 & Lack of willingness of customers to pay for new services and share information. & $\mathrm{x}$ & $\mathrm{X}[13]$ & & & & $\mathrm{x}$ & & $\mathrm{x}$ & & $\mathrm{x}$ & & & [13], [16], [17] \\
\hline 29 & The inaccuracy of predicting customer usage, market demand and evaluation of service potential. & $\mathrm{x}$ & $\mathrm{x}[7]$ & $\mathrm{x}$ & $\mathrm{x}$ & & & & & & $\mathrm{x}$ & & & [7], [14], [15] \\
\hline 30 & Financial partnership formation with customers. & & $\mathrm{X}$ & $\mathrm{x}$ & & & $\mathrm{x}$ & & & $\mathrm{x}$ & & $\mathrm{x}$ & & {$[5],[12],[18]$} \\
\hline 31 & $\begin{array}{l}\text { The potentially large initial investment to produce the solution and retain the ownership with an uncertainty of } \\
\text { ROI period and size. }\end{array}$ & $\mathrm{x}$ & $\mathrm{x}[7]$ & & & & $\mathrm{x}$ & $\mathrm{x}$ & & & & $\mathrm{x}$ & & [3], [7], [24] \\
\hline 32 & Challenges in collaboration with different competence stakeholders in a common decision-making process. & $\mathrm{x}$ & $\mathrm{X}[13]$ & & $\mathrm{x}$ & $\mathrm{x}$ & $\mathrm{x}$ & & & & & & & [13], [25] \\
\hline 33 & Development of new sales and aftersales strategies. & $\mathrm{x}$ & $\mathrm{x}$ & & $\mathrm{x}$ & & & & & & $\mathrm{x}$ & $\mathrm{x}$ & & [7], [12] \\
\hline 34 & Customer segmentation criteria and identification of the right customer groups. & $\mathrm{x}$ & $\mathrm{X}[12]$ & & & & & & & & & & & [12], [17] \\
\hline 35 & Customers may have difficulties when evaluating the quality and reliability of the offering. & $\mathrm{x}$ & $\mathrm{X}[12]$ & & & & $\mathrm{x}$ & & $\mathrm{x}$ & & & & & [12], [25] \\
\hline 36 & $\begin{array}{l}\text { It could be difficult to infuse services into the organization with a traditionally product-focused organization, } \\
\text { which often will maintain its existing priorities - the need for a separate service organisation. }\end{array}$ & $\mathrm{x}$ & $\mathrm{x}[7]$ & & & & & & & & & & & [16], [7] \\
\hline 37 & Difficulties to fully understand customers' need before developing new value propositions. & & $\mathrm{x}$ & & & & $\mathrm{x}$ & & & & & & & [12] \\
\hline 38 & $\begin{array}{l}\text { The network has to make an explicit decision about the degree of standardization of the service offered in order } \\
\text { to balance between the transferability of services across markets vs customization for individual end-users. }\end{array}$ & & $\mathrm{x}$ & & & $\mathrm{x}$ & & & & $\mathrm{x}$ & $\mathrm{x}$ & & & [7] \\
\hline 39 & Increasing the quality and durability of products might reduce future service revenues. & & $\mathrm{x}$ & $\mathrm{x}$ & & & & & & & & $\mathrm{x}$ & & [7] \\
\hline 40 & The ability to manage large organizations of service personnel. & & $\mathrm{x}[7]$ & & & & $\mathrm{x}$ & & & & $\mathrm{x}$ & $\mathrm{x}$ & & [7] \\
\hline
\end{tabular}


Some of the strongest barriers that impose themselves on the development and implementation of PSS are mostly connected to the lack of knowledge on how to do the process, whether the risks of embarking on the service-oriented journey are surpassed by the benefits, and the balancing of environmental goals with satisfying customer priorities (Mont, 2004).

\section{DISCUSSION}

Having uncovered the 29 drivers and 40 barriers for PSS development and implementation, the following discussion of the results is made in the context of the empirical case for this research, namely including observations made at a company which is in the business of producing machinery for the food and beverage industry - and on its way to transitioning to PSS. At the time of writing, the empirical case research is in its maturation phase, for which the identified drivers and barriers will be used to guide and observe the transition in the company setting.

\subsection{Drivers and barriers ratio}

The analysis represented in Figure 1 shows that relatively many drivers fall in the dimension of strategy, followed by ecosystem and economic sustainability. A conclusion is drawn that companies see PSS development as a strategic concern, which goes well with the formation of strong partnerships (ecosystem) to gain economic growth and sustainability. Similarly, the biggest barriers seem to be connected with the ecosystem, change management and PSS development, followed by strategic barriers.

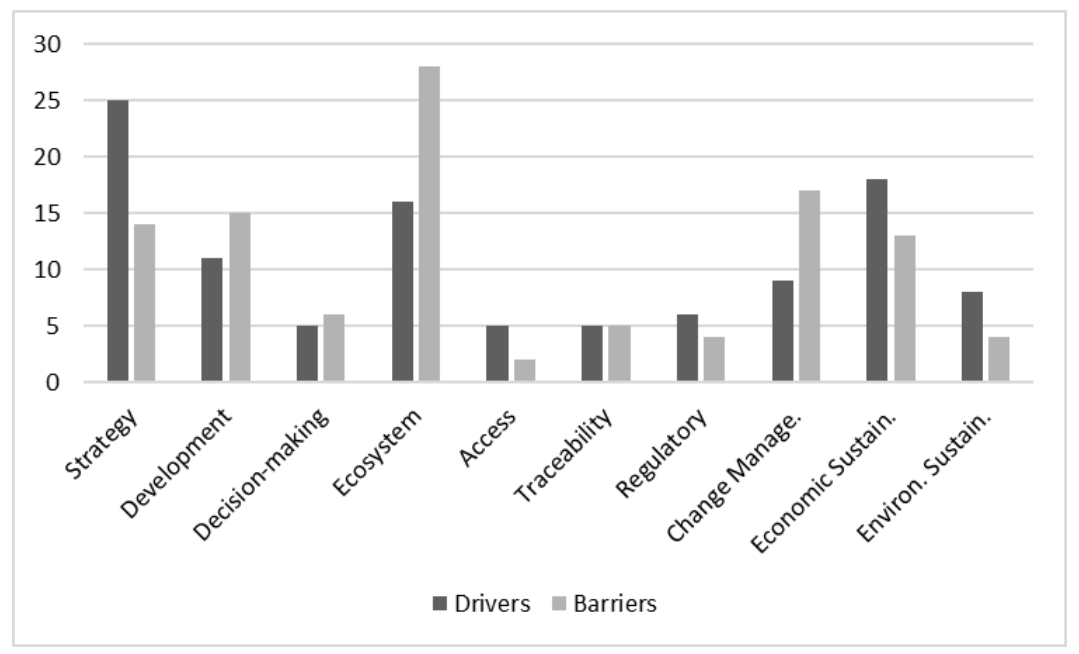

Figure 1. Incidence of drivers and barriers in each dimension.

When observing barriers and the incidence ratio of drivers and barriers within the same dimension, three dimensions stand out - development, ecosystem and change management. The latter two might owe to the fact that there are many uncertainties involved when addressing this dimension, especially relating to the unpredictability of human interaction, and service intangibility. When speaking about the development dimension, a possible explanation is the lack of comprehensive methodologies for PSS development and business-wide implementation. There is, furthermore, a relatively big number of drivers uncovered concerning the environmental sustainability dimension. It is argued that companies are starting to recognize environmental sustainability as a potential outcome of PSS. However, it is challenging to assess this dimension of a PSS, especially in the early phase of system development.

\subsection{MIIG versus CGM}

Many similarities have been uncovered between drivers and barriers for manufacturing companies in general and capital goods manufacturing company. This is likely due to the lack of literature focused on PSS in capital goods manufacturing companies, leading to a scarcer occurrence in the analysis.

However, almost all of the drivers might be valid for a capital goods manufacturer. The distinction can be made between the two, with respect to the focus on the installed base of products, which is where most of the focus of a capital good, especially heavy machinery manufacturer, should go.

An inherent characteristic of products in the capital goods manufacturing industry are often long lifetimes and relatively high investment costs to produce a single equipment unit. Hence, the opportunity to 
ameliorate those products and rise to the level of a PSS poses itself as a promising opportunity. For many manufacturers, especially in $\mathrm{B} 2 \mathrm{~B}$, an already existing installed base of products (i.e. the total number of products currently under use) is a critical resource (Ulaga and Reinartz, 2011).

The case company views PSS as a means to obtain valuable insights about product use that can be fed back to product development (driver \#15, barrier \#31). This can be done through extended product responsibility (EPR), which requires access to customers' facilities and/or data for monitoring and maintenance. However, several reasons for EPR adoption exist, including to shape a clearer cost structure over the whole lifetime of a product (drivers \#28, \#30, barrier \#28); to better allocate responsibility and costs between the company and customers (barrier \#1, \#32); to increase the aftermarket control (driver \#9); and to allow developing more advanced and proactive services and revenue models (drivers \#25, \#27).

One of the most important drivers, in this case, is strategic management commitment to be ahead of the competition (driver \#24). Very much like in most of the manufacturing industry, primary drivers of the case capital goods manufacturer to investigate PSS are of commercial nature (driver \#25). Namely, to explore new growth possibilities (driver \#2) and potentially differentiate from the competition by the expansion of offerings (driver \#24), mainly around services. This incentive has already been recognized by Mont (2004) in mature industries, such as the production of food and beverage manufacturing machinery, where new services can stimulate growth because the possibilities to invent new technical solution have been depleted (driver \#17).

The case company is furthermore motivated for action by environmental consciousness (driver \#23) and the circularity potential of transitioning to PSS (driver \#19), as there is a lack of understanding of how can services and PSS contribute to more circular business models (barrier \#19) and consequently to a more sustainable economy in capital goods manufacturing companies (driver \#19).

\section{CONCLUSION}

In this paper, the main drivers and barriers for PSS development and implementation in manufacturing companies have been reviewed and systematised, giving rise to a number of key clusters to consider.

Manufacturing companies are, in most cases, aware of the key drivers for PSS implementation. Further driver elicitation is therefore useful to strengthen internal motivation for change. On the other hand, companies are, to a greater extent, uncertain of the hurdles and barriers ahead. Understanding key potential barriers can help in managing in minimising uncertainty in the PSS development and implementation process. Even though the case company recognizes numerous drivers for PSS, they find it difficult to detect both the possible and desired scenarios.

Driver and barrier identification, as carried out in this paper, has served to further clarify the potential of PSS in the given setup, as well as to pinpoint the potential barriers ahead. The work from the paper can be operationally used by practitioners to pinpoint the areas of focus and the particular challenges to solve with respect to the drivers that are the most important for the given company. Therefore, the work serves as a palette of challenges that capital goods manufacturers have to consider before immersing in the development of PSS. The next step in this research is to clarify the area of focus for PSS development and implementation to reach key performance and evaluation criteria of PSS in capital goods manufacturing firms.

\section{ACKNOWLEDGMENT}

In addition to the case company, the authors would like to acknowledge the support of the Manufacturing Academy Denmark.

\section{APPENDIX}

Table 5. Key code for references in Drivers and Barriers tables.

\begin{tabular}{|l|l|l|l|}
\hline Reference Key & Reference & Reference Key & Reference \\
\hline$[1]$ & (Mont, 2004) & {$[14]$} & (Meier et al., 2010) \\
\hline$[2]$ & (Baines et a.,, 2007) & {$[15]$} & (Paiola et al., 2013) \\
\hline$[3]$ & (Tukker, 2004) & {$[16]$} & (Kowalkowski et al., 2013) \\
\hline$[4]$ & (Mont, 2002) & {$[17]$} & (Vezzoli et al., 2015) \\
\hline$[5]$ & (Baines et al., 2009) & {$[18]$} & (Windahl et al., 2004) \\
\hline$[6]$ & (Gebauer et al., 2007) & {$[19]$} & (Gebauer and Friedli, 2005) \\
\hline
\end{tabular}




\begin{tabular}{|l|l|l|l|}
{$\left[\begin{array}{l}{[7]} \\
{[8]}\end{array}\right.$} & (Oliva and Kallenberg, 2003) & (Wise and Baumgartner, 2000) \\
\hline$[9]$ & (Malleret, 2006) & {$[21]$} & (Martinez et al., 2010) \\
\hline$[10]$ & (Gebauer et al., 2005) & {$[22]$} & (Neugebauer et al., 2012) \\
\hline$[11]$ & (Mathieu, 2001) & {$[23]$} & (Gebauer et al., 2006) \\
\hline$[12]$ & (Devisscher and Mont, 2008) & {$[24]$} & (Tukker, 2015) \\
\hline$[13]$ & (Adrodegari et al., 2018) & {$[25]$} & (Brown et al., 2011) \\
\hline
\end{tabular}

\section{REFERENCES}

Adrodegari, F., Bacchetti, A., Saccani, N., Arnaiz, A. and Meiren, T. (2018), "The transition towards service-oriented business models: A European survey on capital goods manufacturers”, International Journal of Engineering Business Management, SAGE Publications Inc., Vol. 10, https://dx.doi.org/10.1177/1847979018754469.

de Almeida Biolchini, J.C., Mian, P.G., Natali, A.C.C., Conte, T.U. and Travassos, G.H. (2007), "Scientific research ontology to support systematic review in software engineering", Advanced Engineering Informatics, Elsevier, Vol. 21 No. 2, pp. 133-151. https://dx.doi.org/10.1016/j.aei.2006.11.006.

de Angelis, R. (2018), Business Models in the Circular Economy: Concepts, Examples and Theory, Business Models in the Circular Economy: Concepts, Examples and Theory, Palgrave MacMillan, https://dx.doi.org/10.1007/9783-319-75127-6.

Baines, T.S., Lightfoot, H.W., Benedettini, O. and Kay, J.M. (2009), “The servitization of manufacturing”, Journal of Manufacturing Technology Management, Emerald Group Publishing Limited, Vol. 20 No. 5, pp. 547-567. https://dx.doi.org/10.1108/17410380910960984.

Baines, T.S., Lightfoot, H.W., Evans, S., Neely, A., Greenough, R., Peppard, J., Roy, R., et al. (2007), "State-of-the-art in product-service systems", Journal of Engineering Manufacture, SAGE, Vol. 221 No. 10, pp. 1543-1552. https://dx.doi.org/10.1243/09544054JEM858.

Brown, B., Sichtmann, C. and Musante, M. (2011), "A model of product-to-service brand extension success factors in B2B buying contexts", Journal of Business and Industrial Marketing, Emerald Group Publishing Limited, Vol. 26 No. 3, pp. 202-210. https://dx.doi.org/10.1108/08858621111115921.

Devisscher, T. and Mont, O. (2008), "An analysis of a product service system in Bolivia: Coffee in Yungas", International Journal of Innovation and Sustainable Development, Vol. 3 No. 3-4, pp. 262-284. https://dx.doi.org/10.1504/IJISD.2008.022229.

Ellen MacArthur Foundation. (2015), "Towards a Circular Economy: Business Rationale for an Accelerated Transition", Ellen MacArthur Foundation (EMF), p. 20.

Gebauer, H., Bravo-Sanchez, C. and Fleisch, E. (2007), "Service strategies in product manufacturing companies", Business Strategy Series, Vol. 9 No. 1, pp. 12-20. https://dx.doi.org/10.1108/17515630810850073.

Gebauer, H., Fleisch, E. and Friedli, T. (2005), "Overcoming the service paradox in manufacturing companies", European Management Journal, Pergamon, Vol. 23 No. 1, pp. 14-26. https://dx.doi.org/10.1016/j.emj.2004.12.006.

Gebauer, H. and Friedli, T. (2005), "Behavioral implications of the transition process from products to services", Journal of Business and Industrial Marketing, Emerald Group Publishing Limited, Vol. 20 No. 2, pp. 70-78. https://dx.doi.org/10.1108/08858620510583669.

Gebauer, H., Friedli, T. and Fleisch, E. (2006), "Success factors for achieving high service revenues in manufacturing companies”, Emerald GPL, Vol. 13 No. 3, pp. 374-386. https://dx.doi.org/10.1108/14635770610668848.

Gebauer, H., Paiola, M. and Edvardsson, B. (2010), "Service business development in small and medium capital goods manufacturing companies", Managing Service Quality, Emerald Group Publishing Limited, Vol. 20 No. 2 , pp. 123-139. https://dx.doi.org/10.1108/09604521011027561.

Haase, R.P., Pigosso, D.C.A. and McAloone, T.C. (2017), "Product/Service-System Origins and Trajectories: A Systematic Literature Review of PSS Definitions and their Characteristics", Procedia CIRP, The Author(s), Vol. 64, pp. 157-162. https://dx.doi.org/10.1016/j.procir.2017.03.053.

Kim, Y.S. and Lee, H. (2020), "Process Characteristics of Product-Service Systems Development: Comparison of Seven Manufacturing Company Cases”, Journal of Cleaner Production, Elsevier, Vol. 286, p. 124971. https://dx.doi.org/10.1016/j.jclepro.2020.124971.

Kjaer, L.L., Pigosso, D.C.A.A., Niero, M., Bech, N.M., McAloone, T.C., Niero, M. and Bech, N.M. (2019), "Product/Service-Systems for a Circular Economy: The Route to Decoupling Economic Growth from Resource Consumption?", Journal of Industrial Ecology, Vol. 23 No. 1, pp. 22-35. https://dx.doi.org/10.1111/jiec.12747.

Kowalkowski, C., Kindström, D. and Gebauer, H. (2013), "ICT as a catalyst for service business orientation", Journal of Business and Ind. Marketing, Vol. 28 No. 6, pp. 506-513. https://dx.doi.org/10.1108/JBIM-04-2013-0096.

Malleret, V. (2006), "Value creation through service offers", European Management Journal, Pergamon, Vol. 24 No. 1, pp. 106-116. https://dx.doi.org/10.1016/j.emj.2005.12.012. 
Manzini, E. and Vezzoli, C. (2003), “A strategic design approach to develop sustainable product service systems: Examples taken from the 'environmentally friendly innovation' Italian prize”, Journal of Cleaner Production, Elsevier Ltd, 1 December. https://dx.doi.org/10.1016/S0959-6526(02)00153-1.

Martinez, V., Bastl, M., Kingston, J. and Evans, S. (2010), “Challenges in transforming manufacturing organisations into product-service providers”, Journal of Manufacturing Technology Management, Vol. 21 No. 4, pp. 449-469. https://dx.doi.org/10.1108/17410381011046571.

Mathieu, V. (2001), "Service strategies within the manufacturing sector: Benefits, costs and partnership", International Journal of Service Industry Management, Vol. 12 No. 5, pp. 451-475. https://dx.doi.org/10.1108/EUM0000000006093.

Matthyssens, P. and Vandenbempt, K. (2008), "Moving from basic offerings to value-added solutions: Strategies, barriers and alignment”, Industrial Marketing Management, Elsevier, Vol. 37 No. 3, pp. 316-328. https://dx.doi.org/10.1016/j.indmarman.2007.07.008.

McAloone, T.C. (2011), "Boundary Conditions for a New Type of Design Task: Understanding Product/ServiceSystems", The Future of Design Methodology, pp. 113-124. https://dx.doi.org/10.1007/978-0-85729-615-3_10.

Meier, H., Roy, R. and Seliger, G. (2010), “Industrial Product-Service systems-IPS2”, CIRP Annals - Manufacturing Technology, Elsevier, Vol. 59 No. 2, pp. 607-627. https://dx.doi.org/10.1016/j.cirp.2010.05.004.

Mendes, G.H.S., Oliveira, M.G., Rozenfeld, H. and Marques, C.A.N. (2015), "Product-Service System (PSS) Design Process Methodologies: a Systematic Literature Review”, ICED15, Vol. 7 No. July, pp. 291-300.

Mont, O. (2004), "Drivers and barriers for shifting towards more service-oriented businesses: Analysis of the PSS field and contributions from Sweden”, The Journal of Sustainable Product Design, Springer Nature, Vol. 2 No. 3/4, pp. 89-103. https://dx.doi.org/10.1023/b:jspd.0000031027.49545.2b.

Mont, O.K. (2002), "Clarifying the concept of product-service system”, Journal of Cleaner Production, Elsevier, Vol. 10 No. 3, pp. 237-245. https://dx.doi.org/10.1016/S0959-6526(01)00039-7.

Neugebauer, L.M., Mougaard, K., Andersen, J.A.B., McAloone, T.C., Bey, N., Hsuan, J. and Ahm, T. (2012), PSS Case Book, A Workbook in the PROTEUS Series.

Oliva, R. and Kallenberg, R. (2003), "Managing the transition from products to services", International Journal of Service Industry Management, Vol. 14 No. 2, pp. 160-172. https://dx.doi.org/10.1108/09564230310474138.

Opresnik, D., Zanetti, C. and Taisch, M. (2013), "Servitization of the manufacturer's value chain", Advances in Information and Communication Technology, Vol. 415, pp. 234-241. https://dx.doi.org/10.1007/978-3-642-41263-9_29.

Paiola, M., Saccani, N., Perona, M. and Gebauer, H. (2013), "Moving from products to solutions: Strategic approaches for developing capabilities”, European Management Journal, Pergamon, Vol. 31 No. 4, pp. 390-409. https://dx.doi.org/10.1016/j.emj.2012.10.002.

Prahalad, C.K. and Ramaswamy, V. (2004), "Co-creation experiences: The next practice in value creation", Vol. 18, pp. 5-14. https://dx.doi.org/10.1002/dir.20015.

Roy, R. (2000), “Sustainable product-service systems”, Futures, Pergamon, Vol. 32 No. 3-4, pp. 289-299. https://dx.doi.org/10.1016/S0016-3287(99)00098-1.

Stahel, W.R. (2019), The Circular Economy: A User's Guide, Routledge, London, https://dx.doi.org/10.4324/9780429259203

Tersine, R.J. and Hummingbird, E.A. (1995), "Lead-time reduction: The search for competitive advantage", International Journal of Operations and Production Management, https://dx.doi.org/10.1108/01443579510080382.

Tukker, A. (2004), "Eight types of product-service system: Eight ways to sustainability? Experiences from suspronet", Business Strategy and the Environment, Vol. 13 No. 4, pp. 246-260. https://dx.doi.org/10.1002/bse.414.

Tukker, A. (2015), "Product services for a resource-efficient and circular economy - A review", Journal of Cleaner Production, Elsevier Ltd, 15 June. https://dx.doi.org/10.1016/j.jclepro.2013.11.049.

Ulaga, W. and Reinartz, W.J. (2011), "Hybrid Offerings: How Manufacturing Firms Combine Goods and Services Successfully”, Journal of Marketing, AMA, Vol. 75 No. 6, pp. 5-23. https://dx.doi.org/10.1509/jm.09.0395.

Vezzoli, C., Ceschin, F., Diehl, J.C. and Kohtala, C. (2015), "New design challenges to widely implement 'Sustainable Product-Service Systems"”, Journal of Cleaner Production, Elsevier Ltd, Vol. 97, pp. 1-12. https://dx.doi.org/10.1016/j.jclepro.2015.02.061.

Vezzoli, C., Ceschin, F., Osanjo, L., M'Rithaa, M.K., Moalosi, R., Nakazibwe, V. and Diehl, J.C. (2018), "Sustainable Product-Service System (S.PSS)", Green Energy and Technology, Springer Verlag, pp. 41-51. https://dx.doi.org/10.1007/978-3-319-70223-0_3.

Windahl, C., Andersson, P., Berggren, C. and Nehler, C. (2004), "Manufacturing firms and integrated solutions: Characteristics and implications", European Journal of Innovation Management, Emerald Group Publishing Limited, Vol. 7 No. 3, pp. 218-228. https://dx.doi.org/10.1108/14601060410549900.

Wise, R. and Baumgartner, P. (2000), "Go downstream: The new profit imperative in manufacturing”, IEEE Engineering Management Review, Vol. 28 No. 1, pp. 89-96.

Wohlin, C. (2014), "Guidelines for snowballing in systematic literature studies and a replication in software engineering”, Association for Computing Machinery, USA, pp. 1-10. https://dx.doi.org/10.1145/2601248.2601268. 